\title{
Karina Stempel-Gancarczyk
}

\section{Piętno a wartość języka. Sytuacja gwar małopolskich na Bukowinie rumuńskiej}

\section{Wstęp}

określonych warunkach społeczno-politycznych język może być postrzegany
jako piętno. Anna Zielińska, pisząc o tym zjawisku i określając język jako atrybut
miejsca pochodzenia - a więc kategorii będącej podstawą zróżnicowania etnicznego - wyodrębnia trzy etapy działania piętna: rozpoznanie różnicy, nałożenie maski oraz stygmatyzację (Zielińska, 2013, ss. 242-255). Autorka Mowy pogranicza zauważa, że język należy do grupy atrybutów, które najłatwiej jest poddać stygmatyzacji:

Mówienie jakimś językiem lub używanie słów z jakiegoś języka, nawet istnienie cech fonetycznych, gramatycznych to fakty "widoczne" lub raczej „dostępne percepcji”, bo są słyszalne; to znaczy, że skutecznie komunikują o istnieniu piętna pochodzenia (tak jak cechy wyglądu mogą informować o piętnie kalectwa) (Zielińska, 2013, s. 242).

Jak wynika z badań gwar małopolskich na Bukowinie rumuńskiej', efekt piętna w odniesieniu do języka można rozpatrywać nie tylko w kontekście kategoryzacji spo-

\footnotetext{
${ }^{1}$ Badania te były prowadzone przez autorkę artykułu w latach 2013-2019. Ich efektem jest rozprawa doktorska Procesy zanikania języka na podstawie badań gwar polskich na Bukowinie rumuńskiej, której publiczna obrona odbyła się w Instytucie Slawistyki PAN w Warszawie 25.06.2019 r. (Stempel-Gancarczyk, 2019). W pracy przedstawione zostały zastosowane metody
} 
łecznej oraz normatywności (Zielińska, 2013, s. 239). Oczywiście, w tym kontekście należy analizować go przede wszystkim w relacji do języka dominującego (w tym wypadku rumuńskiego). Warto jednak uwzględnić również perspektywę samych użytkowników gwar: sytuujących się w odniesieniu do grup Polaków mówiących innymi rodzajami polszczyzny gwarowej w Rumunii oraz w stosunku do osób posługujących się językiem ogólnopolskim (nauczycieli, turystów z Polski lub tych członków społeczności, którzy np. ukończyli w Polsce studia lub tam mieszkają itp.). W obu tych przypadkach działanie piętna zachodzi w taki sposób, w jaki opisał to Erving Goffman: „Tam, gdzie odmienność jest względnie niewidoczna, jednostka musi się nauczyć tego, że w rzeczywistości może polegać na swojej skrytości" (Goffman, 2005, s. 119). Użytkownicy wszystkich funkcjonujących na Bukowinie gwar polskich konfrontują swój język nie tylko z językiem dominującym - rumuńskim, ale też innymi gwarami polskimi oraz polszczyzną ogólną. Nierzadko ta "konfrontacja” w opinii samych Polaków z Bukowiny ${ }^{2}$ wypada dla nich niekorzystnie (por. Zielińska, 2013, s. 239 i in.). W praktyce oznacza to często wycofanie gwary z użycia we wszystkich domenach.

Badania gwar polskich w Rumunii skłaniają do wysunięcia hipotezy, że piętno najsilniej oddziałuje tam, gdzie nie zostało wyeksplikowane, gdzie problem języka istnieje w świadomości użytkowników, ale nie mówi się o nim „głośno”, a więc nie nazywa się go „problemem”. W dalszej części artykułu poruszona zostanie kwestia zaniku gwar polskich w sytuacji, gdy pośród żyjących w tym samym państwie, na tym samym obszarze i w jednakowych warunkach społeczno-politycznych społeczności polskich tylko jedna z nich - tzw. górale bukowińscy zachowuje transmisję pokoleniową gwary. Jak się wydaje, czynnikiem, który za to odpowiada, są specyficzne, wyjątkowe na tle pozostałych grup, uwarunkowania historyczne, a mianowicie sytuacja, w której kwestia problematyczności języka została wyrażona wprost, a jego wartość podważona w sposób bezpośredni - i w związku z tym użytkownicy uświadomili sobie jego znaczenie. Stało się tak wyłącznie w wypadku górali bukowińskich. W świetle prowadzonych

badawcze oraz materiał egzemplifikujący omawiane zagadnienia (m.in. fragmenty wywiadów z członkami badanych społeczności). Na ten temat por. także: Stempel-Gancarczyk, 2015, 2016a, 2016b, 2017a, 2017b, 2018 i inne.

2 Podczas ostatniego spisu powszechnego w Rumunii, przeprowadzonego w 2011 roku, narodowość polską zadeklarowały jedynie 2543 osoby, z czego 1922 w województwie suczawskim (na terenie Bukowiny rumuńskiej) (Institutul Naţional de Statistică, b.d.-b - tab. 2). Polacy mieszkający w Rumunii mają status mniejszości narodowej; w myśl prawa za mniejszość narodową w Rumunii uważa się osoby o innej niż rumuńska narodowości, których legalnie ukonstytuowana organizacja jest członkiem Rady Mniejszości Narodowych, a jej reprezentanci zasiadają w Izbie Deputowanych. Prawa mniejszości oraz ich ochronę określa Konstytucja Rumunii (przede wszystkim art. 6 Prawo do tożsamości: „Państwo uznaje i gwarantuje osobom należącym do mniejszości narodowych prawo do zachowania, rozwijania i wyrażania swojej tożsamości etnicznej, kulturowej, językowej i religijnej"; art. 6 (1), cyt. za: Konstytucja Rumunii, b.d.; por. także Wieruszewska, 2006, ss. 267-269). 
analiz wydaje się, że tylko w odniesieniu do tej jednej społeczności polskiej na Bukowinie rumuńskiej doszło do zmiany charakteru piętna, paradoksalnie zwiększającej prestiż gwary.

\section{Gwary polskie na Bukowinie rumuńskiej - zarys problematyki}

Bukowina to kraina historyczna obecnie leżąca na terytorium dwóch państw: Rumunii i Ukrainy. W początkowym okresie jej funkcjonowania jako jednostki politycznej, w okresie zwierzchnictwa Austrii (1774-1918) rozpoczęła się akcja osadnicza, która zaowocowała osiedlaniem się ludności polskiej na tym terenie. Na ziemie należące obecnie do Rumunii (czyli na tzw. Bukowinę Południową) jako pierwsi Polacy w tamtym czasie przybyli górnicy z Bochni, których do migracji skłoniła możliwość podjęcia pracy przy eksploatacji złóż soli kamiennej. Zaczęli się oni osiedlać w miejscowości Kaczyka w latach 1791-1792. Następnie do Kaczyki przybywały kolejne rodziny górnicze z Bochni, Wieliczki i Kałusza. W latach 1834-1842 tzw. górale bukowińscy (przybywający na Bukowinę z okolic Czadcy) założyli wsie Nowy Sołoniec, Pleszę i Pojanę Mikuli. Wsie Ruda (obecnie Wikszany) i Bulaj powstawały od połowy XIX wieku, tworzone przez osadników z okolic Rzeszowa, a w wypadku Rudy również Sanoka.

Potomkowie przybyłych wówczas do Rumunii Polaków żyją na Bukowinie rumuńskiej do dzisiaj ${ }^{3}$ i tworzą cztery grupy użytkowników polszczyzny, co pozwoliło w latach 60. XX wieku wyodrębnić cztery gwary polskie na terytorium Rumunii. Podziału tego dokonali Elena Deboveanu i Stanisław Gogolewski w artykule Przegląd polskich gwar na terenie Rumunii (Deboveanu \& Gogolewski, 1966). Opisane przez nich rodzaje polszczyzny ${ }^{4}$ różniły się od siebie specyficznymi cechami językowymi, powiązanymi z miejscem pochodzenia ich użytkowników. Były to: a) gwara wsi Kaczyka, b) gwara tzw. górali bukowińskich, c) gwara wsi Ruda, d) gwara wsi Bulaj i Mihoweny.

\footnotetext{
${ }^{3}$ Ten skrócony opis nie obejmuje problemu emigracji politycznej (m.in. popowstaniowej, a w wieku XX również wojennej). Polscy osadnicy mieszkali i osiedlali się również w wielu innych miejscowościach. Śladem i świadectwem historii Polaków na Bukowinie są miejscowości, w których osoby posługujące się mową polską znaleźli w latach 2015-2018 wykonawcy grantu Mowa polska na Bukowinie Karpackiej. Dokumentacja zanikajacego dziedzictwa narodowego (Krasowska i in., 2018, s. 58). Są to: Arbore, Bulaj, Frumosa, Gura Humorului, Kaczyka, Kympulung Mołdawski, Mihoweny, Nowy Sołoniec, Paltynosa, Plesza, Pojana Mikuli, Radowce, Seret, Suczawa, Waszkowce i Ruda (Wikszany). Więcej na temat osadnictwa polskiego na Bukowinie (Biedrzycki, 1973; Petraru, 2004 i in.).

${ }^{4}$ Deboveanu i Gogolewski opisali gwary polskie na terenie Rumunii - w rzeczywistości wszystkie posługujące się nimi społeczności żyły na terenie Bukowiny rumuńskiej.

5 Oryginalny zapis wskazywał na "tzw. Górali bukowińskich” oraz miejscowość „Michoweny”. W niniejszym artykule zastosowano zapis tych nazw jak we współczesnych opracowaniach.
} 


\section{Gwary małopolskie (Bulaj, Ruda, Wikszany) - język jako zanikające świadectwo}

Obserwacje przedstawione w niniejszym artykule odnoszą się bezpośrednio do podziału gwar autorstwa E. Deboveanu i S. Gogolewskiego ${ }^{6}$. Badania prowadzone przez autorkę artykułu od roku 2013 koncentrowały się na analizie socjolingwistycznej, a następnie opisie trzech z wymienionych przez językoznawców gwar, a mianowicie tzw. gwar małopolskich: wsi Bulaj i Mihoweny (oraz Frumosa)', wsi Kaczyka i wsi Wikszany ${ }^{8}$. Stały się one podstawą do sformułowania tezy, że te trzy gwary zanikają - i jest to proces zbieżny z tak zwaną "śmiercią języka"9.

Jeffrey Holdeman, na podstawie badań prowadzonych w społeczności staroobrzędowców, w dysertacji Language maintenance and shift among the Russian Old Believers of Erie, Pennsylvania wyszczególnił oznaki zmiany i śmierci języka mniejszości (Sings of Language Shift and Death) (Holdeman, 2002, s. 14; tłumaczenie za: Głuszkowski, 2011, s. 251). Opisane przez niego zjawiska można zauważyć, analizując sytuację gwar Bulaju, Rudy i Kaczyki. Ich paralelność pozwala zweryfikować tezę dotyczącą procesów zanikania gwar małopolskich na Bukowinie rumuńskiej ${ }^{10}$. Oznakami tymi są:

- Zanikanie własnych struktur językowych i adaptacja obcych - w wypadku badanych gwar polskich przykładem może być pojawienie się zmian w wymowie i repertuarze głosek: modyfikacja wymowy samogłosek o i y, a także wzbogacenie o rumuńską samogłoskę ă (ə) w wypadku gwary Bulaju, zastąpienie wargowej lub zębowej realizacji ł dawnego I (twardego) przez dziąsłowe / w Rudzie i Kaczyce, czy pojawienie się

\footnotetext{
${ }^{6}$ Najnowsze ustalenia dotyczące problemu gwar na Bukowinie zaprezentowała Helena Krasowska w książce Świadectwo zanikajqcego dziedzictwa. Mowa polska na Bukowinie: Rumunia - Ukraina (Krasowska i in., 2018), będącej podsumowaniem badań prowadzonych w ramach grantu Mowa polska na Bukowinie Karpackiej. Dokumentacja zanikajqcego dziedzictwa narodowego, (NPRH, nr 1bH 150354 83), realizowanego w latach 2015-2018. H. Krasowska podzieliła mowę Polaków na Bukowinie (ujmowanej jako całościowa kraina historyczna, a więc obejmującej współcześnie zarówno ziemie rumuńskie, jak i ukraińskie) następująco: 1) polszczyzna bukowińska, która jest kontynuacją polszczyzny południowo-wschodnich Kresów; 2) gwara górali bukowińskich; oraz 3) gwara wsi Bulaj z cechami dialektu małopolskiego. Autorka wyróżniła także i opisała cechy zanikającej mowy Polaków w Wikszanach (Rudzie) i Kaczyce (por. Krasowska i in., 2018, ss. 84, 123).

${ }^{7}$ W literaturze funkcjonuje również zapis Frumoasa. Mieszkańcy tej miejscowości posługują się tą samą gwarą co mieszkańcy Bulaju.

${ }^{8}$ Wikszany (Vicşani) to nazwa obowiązująca od roku 1918. Wieś znana jest także i występuje w literaturze przedmiotu pod polską nazwą Ruda.

${ }^{9}$ Problem ten, ze wskazaniem jego przyczyn i skutków, autorka analizuje we wspomnianej pracy doktorskiej pt. Procesy zanikania języka na podstawie badań gwar polskich na Bukowinie rumuńskiej (Stempel-Gancarczyk, 2019).

${ }^{10}$ Przedstawione konkluzje są efektem analizy sytuacji socjolingwistycznej w badanych miejscowościach: Bulaju (Mihowenach i Frumosie), Rudzie i Kaczyce (por. Stempel-Gancarczyk, 2019).
} 
w mowie mieszkańców Kaczyki zmiękczonych przedniojęzykowych głosek $s^{\prime} z^{\prime} c^{\prime} d z^{\prime}$ w miejsce środkowojęzykowych śź ć dź;

- Redukcja złożoności i różnorodności kategorii gramatycznych - przejawiająca się m.in. w uproszczeniu deklinacji i koniugacji;

- Zanikanie norm językowych - szczególnie dobrze widoczne w kontekście interferencji zauważalnych w mowie mieszkańców badanych miejscowości oraz stopniu zróżnicowania idiolektów poszczególnych mieszkańców;

- Ograniczenia funkcjonalne związane z zawężeniem zakresu tradycyjnego zastosowania - w wypadku większości użytkowników mówić można o wycofaniu mowy polskiej z użycia w domu i w sąsiedztwie, nie jest to także język szkoły ani liturgii; efektem tego jest sytuacja, w której użytkownikom gwary „brakuje słów” na określenie przedmiotów lub czynności życia codziennego;

- Zubożenie zestawu rejestrów i stylów - przejawiające się w ograniczonym zakresie użycia języka, nieużywaniu go w piśmie, a w skrajnych przypadkach również w zjawisku atrycji języka (Libura, 2014, s. 305);

- Nadmierna liczba zapożyczeń - zapożyczenia pojawiają się także w sferach, w których wcześniej dominowało słownictwo gwarowe: w wypowiedziach dotyczących czynności życia codziennego czy obrzędów świątecznych;

- Poczucie niższości u użytkowników danego języka - które wiąże się z dążeniem do wyrównania szans społecznych przez użytkowników gwar polskich, w czym ich zdaniem pomaga wychowanie dzieci w języku większości (rumuńskim);

- Zmiana języka liturgii na język większości - obserwowana we wszystkich badanych miejscowościach;

- Przejście na język większości w sferze domowej - z nielicznymi wyjątkami obserwowane we wszystkich badanych społecznościach;

- Brak pokoleniowej transmisji języka - w wypadku Bulaju, Rudy i Kaczyki pokolenie najmłodsze w ogóle nie posługuje się już gwarą polską, a pokolenie średnie tylko wyjątkowo lub w znikomym zakresie;

- Przeciwstawienie mentalności „my” i „oni" ${ }^{\prime 11}$ - czyli świadomość własnej odrębności oraz wynikające z niej poczucie braku równych szans w awansie społecznym pro-

\footnotetext{
" Lub inaczej „naszej" $\mathrm{i}$ „ich” („»us« versus »them« mentality among speakers”, por. Holdeman, 2002, s. 15); tłum. własne.
} 
wadziły w minionych dziesięcioleciach do wycofywania z użycia w życiu domowym i społecznym mowy polskiej. Użytkownicy polszczyzny dostrzegali także odmienność swojej polszczyzny od języka ogólnopolskiego, co wpłynęło na znaczące obniżenie prestiżu gwar.

W odniesieniu do gwar w Bulaju, Rudzie i Kaczyce zauważyć można wszystkie z wymienionych powyżej cech świadczących o zaawansowanym procesie zaniku języka, prowadzącym do jego śmierci. Najbardziej widoczny jest on w leżących w pobliżu Bulaju Mihowenach i Frumosie, gdzie żyje tylko kilka osób posługujących się zachowaną gwarą. We wszystkich analizowanych gwarach małopolskich w Rumunii dostrzec można zaawansowane procesy interferencyjne, które dotyczą różnych podsystemów języka: fonetycznego i fonologicznego, morfologicznego, frazeologicznego, stylistycznego, składniowego i leksykalnego.

Na obecną sytuację językową bardzo duży wpływ miała rumunizacja, jakiej doświadczyli mieszkańcy badanych wsi przed 1989 rokiem. A. Zielińska zwraca uwagę, że „to ideologie kierują sposobami, w jakie jednostki i grupy używają swoich języków. W społecznościach wielojęzycznych wybory językowe zawsze są znaczące i związane z pytaniami o tożsamość" (Zielińska, 2013, s. 139) - tak właśnie stało się również w wypadku polskich społeczności na Bukowinie rumuńskiej.

Rumunizacyjna polityka państwa w okresie międzywojennym, a następnie likwidacja nauki języka mniejszości w szkołach w latach 1962-1992 (por. Stempel-Gancarczyk, 2016a, 2017b, 2018), spowodowały znaczne obniżenie prestiżu gwar w oczach ich użytkowników. W powojennej Rumunii kwestie tożsamości członków mniejszości narodowych oraz ich języków zostały zepchnięte na margines. O zmianach, jakie dotknęły w tamtym okresie całą Bukowinę, pisał Kazimierz Feleszko:

Przed półwieczem wtargnął na Bukowinę system, który nie tylko unicestwił jej jedność, ale też rozpędził po świecie jej wielojęzycznych mieszkańców. Dokonawszy tego, przystąpił do niszczenia gospodarki, kultury, przyrody i wreszcie - do niszczenia od wewnątrz człowieka, przez wtłaczanie go w duchowy uniform "homo sovieticus" (Feleszko, 1999, s. 6).

Już na wczesnych etapach socjalizacji dzieci z rodzin polskich (lub rodzin mieszanych, w których używano gwary polskiej) dowiadywały się, że używanie polszczyzny nie jest zgodne ze standardami obowiązującymi w życiu społecznym miejscowości, w których żyły. Piętno języka, jak już wspomniano we wstępie, jest piętnem wyjątkowym, jeśli chodzi o aspekt jego "widoczności" rozumianej jako kwestia, czy piętno jest na tyle oczywiste, aby nie dało się go ukryć (Goffman, 2005, ss. 84-87). W wypadku języka strategią pozwalającą 
na ukrycie piętna (czyli nałożenie maski - por. Goffman, 2005, ss. 38-39 oraz Zielińska, 2013, s. 243) jest wycofanie języka z użycia. Strategia ta nie sprawdza się zawsze - np. trudno stosować ją w odniesieniu do najbliższego otoczenia, jak rodzina czy sąsiedztwo - jak zauważył Goffman, w wypadku piętna „zażyłość nie musi redukować pogardy” (Goffman, 2005, s. 89). Użytkownicy polszczyzny starali się jednak wyrugować gwarę polską z użycia nie tylko w przestrzeni publicznej (w tym w szkole), ale także w sferze sąsiedzkiej i domowej. Miało to na celu jak najlepsze opanowanie języka rumuńskiego oraz utrudniało identyfikację etniczną - co w oczach użytkowników gwar stanowiło dobrą taktykę, zapewniającą nie tylko zwiększenie szans awansu społecznego, lecz także uniknięcie stygmatyzacji. Z tego właśnie powodu nastąpiła radykalna zmiana w obszarze komunikacyjnym: zaprzestano transmisji gwary w rodzinach. Bieżące problemy życiowe i konieczność radzenia sobie w zmieniającej się rzeczywistości społecznej spowodowały, że w wypadku Bulaju, Rudy i Kaczyki tożsamość społeczna (czyli bycie członkiem społeczeństwa rumuńskiego) stała się bardziej istotna niż tożsamość osobista, której elementem było polskie pochodzenie oraz związana z tym znajomość gwary (Goffman, 2005). Strategia, jaką musiano przyjąć w odniesieniu do języka, mogła stać się tożsama z decyzją, czy pozostać przy statusie osoby dyskredytowalnej, czy też świadomie ryzykować zdyskredytowanie (Goffman, 2005, s. 77). Bycie osobą dyskredytowalnq umożliwia funkcjonowanie tak, jakby piętno pozornie nie istniało, a więc pozwala na względną integrację ze społecznością. Efektem strategii obranej przez użytkowników języka jest sytuacja, z jaką mamy do czynienia dzisiaj - w badanych miejscowościach nie ma już dzieci pochodzenia polskiego mówiących gwarą. Obecnie uczą się one języka polskiego (ogólnopolskiego) jedynie w szkołach².

Zanikanie gwar w społecznościach Bulaju, Rudy i Kaczyki zdeterminowane było także (a obecnie: jest przede wszystkim) przez czynniki demograficzne. Autorzy Przeglądu gwar polskich na Bukowinie rumuńskiej podali, że w czasie prowadzonych przez nich badań w Bulaju żyło około 300 Polaków (Deboveanu \& Gogolewski, 1966, s. 128), w Rudzie „około 40 rodzin

\footnotetext{
${ }^{12}$ Ramy prawne nauczania języków mniejszościowych w Rumunii wyznacza Ustawa o nauczaniu nr 1 z 5 stycznia 2011 roku. W rumuńskim Ministerstwie Edukacji sprawami mniejszości narodowych zajmuje się Dyrekcja Mniejszości Narodowych oraz sekretarz stanu ds. mniejszości narodowych. Dyrekcja ma kompetencje do organizacji, koordynacji nauczania w językach mniejszości narodowych, wypracowywania, zatwierdzania treści nauczania, monitorowania jakości nauczania, doradztwa oraz współpracy z innymi instytucjami i organizacjami, takimi jak Departament Relacji Interetnicznych przy Rządzie Rumunii i Rada Mniejszości Narodowych przy DRI (Ministerul Educaţiei Naţionale și Cercetării Științifice, b.d.). W szkołach naucza się języka ojczystego w wymiarze 3-4 godzin tygodniowo (4 dla klas 0-IV, 3 dla klas V-VIII i licealnych). W klasach VI i VII prowadzi się także nauczanie przedmiotu "Historia i tradycje mniejszości narodowych” w wymiarze jednej godziny tygodniowo (możliwe jest także nauczanie w języku ojczystym religii i wychowania muzycznego) (Ministerul Educaţiei și Cercetării, b.d.).
} 
polskich" (Deboveanu \& Gogolewski, 1966, s. 125), w Kaczyce zaś „kilkadziesiąt rodzin”, liczących podobnie jak w Bulaju około 300 członków (Deboveanu \& Gogolewski, 1966, s. 116).

Adam Rossmanith na podstawie własnych badań, prowadzonych na Bukowinie w latach 2011-2013, podaje, że w roku 2012 w Bulaju żyło w polskich rodzinach 99 osób - w tym 72 Polaków, w Rudzie 83 osoby - w tym 48 Polaków, w Kaczyce natomiast 103 osoby - w tym 68 Polaków (Rossmanith, 2017, s. 407) ${ }^{13}$. Aktualnie w każdej z wymienionych miejscowości obserwować można systematyczny spadek tej liczby, a także duże zróżnicowanie w zakresie idiolektów, którymi posługują się użytkownicy polszczyzny.

\section{Górale bukowińscy - język jako wartość}

Obecna sytuacja socjolingwistyczna w społecznościach Bulaju, Rudy i Kaczyki znacząco różni się od sytuacji, w jakiej znajduje się czwarta grupa, wyodrębniona w badaniach gwar polskich na Bukowinie rumuńskiej przez Deboveanu i Gogolewskiego - górale bukowińscy (znani również jako górale czadeccy) zamieszkujący Nowy Sołoniec, Pojanę Mikuli i Pleszę. Gwara oraz sytuacja socjolingwistyczna tej grupy była przedmiotem wielu analiz; swoją pracę doktorską poświęciła jej Helena Krasowska (Krasowska, 2006). Górale polscy na Bukowinie Karpackiej to rozprawa obejmująca opis socjolingwistyczny i leksykalny społeczności górali bukowińskich zamieszkujących zarówno południową (rumuńską), jak i północną Bukowinę.

Grupa ta cieszyła się o wiele większym zainteresowaniem badaczy reprezentujących różne dziedziny nauki niż mieszkańcy Bulaju, Rudy i Kaczyki. Pierwszy opis gwary górali bukowińskich na terenie Rumunii pochodzi z pracy Mieczysława Małeckiego i Grigore Nandrişa (Małecki \& Nandriş, 1938), a Małecki poświęcił jej także część rozprawy Język polski na południe od Karpat (Spisz, Orawa, Czadeckie, wyspy językowe) (Małecki, 1938). Już przed II wojną światową wzmożone zainteresowanie badaczy tą grupą wiązało się ze specyficznymi uwarunkowaniami historycznymi oraz politycznymi.

Jak zauważa etnolog Eugeniusz Kłosek, górale bukowińscy musieli wcześnie określić swoją tożsamość, i to nie tylko w odniesieniu do warunków życia w społeczności rumuńskiej: „Społeczność potomków górali czadeckich stanowi szczególny przypadek z punktu widzenia relacji polsko-słowackich, a dzieje tej niewielkiej grupy odzwierciedlają zawiłości

\footnotetext{
${ }^{13}$ Ogólna liczba mieszkańców tych wsi według spisu powszechnego 2011 była następująca: Bulaj - 1036, Ruda - 227, Kaczyka - 1110 osób (Institutul Naţional de Statistică, b.d.-a - tab. Populaţia stabilă pe judeţe, municipii, oraşe şi localităti componenete la RPL_2011).
} 
stosunków etnicznych środkowej Europy w procesie kształtowania się nowoczesnych społeczeństw narodowych" (Kłosek, 2005, s. 117). Kwestią sporną już od początku XX wieku stało się bowiem pochodzenie górali czadeckich i określenie, czy gwara, jaką się posługują, należy do gwar polskich, czy słowackich. Punktem wyjścia była teza profesora uniwersytetu czerniowieckiego Raimunda F. Kaindla, że mieszkańcy Nowego Sołońca, Pojany Mikuli i Pleszy są Słowakami z okolic Czadcy, a teorie mówiące o polskości ich mowy są efektem celowych działań Kościoła i szkoły (Kłosek, 2005, s. 118). Tezy o polonizacji górali pojawiały się zarówno w piśmiennictwie niemieckim, jak i słowackim oraz rumuńskim (Kłosek, 2005, ss. 118-119). Prace Małeckiego i Nandrişa, podobnie jak opracowania Gotkiewicza (Gotkiewicz, 1938 i inne), Biedrzyckiego (Biedrzycki, 1973) i Deboveanu (Deboveanu, 1971) wskazywały natomiast jednoznacznie na polską genezę gwary górali bukowińskich.

Kwestie językowe stały się w okresie międzywojennym podłożem konfliktu narodowościowego we wsiach zamieszkałych przez górali. Sprzyjała temu sytuacja polityczna w roku szkolnym 1935-1936 usunięto ze szkół rumuńskich języki mniejszości, a jednocześnie zawarta została umowa rumuńsko-czechosłowacka o szkolnictwie, w myśl której dozwolona była nauka języków czeskiego i słowackiego w szkołach, pod warunkiem zgłoszenia grupy co najmniej 30 uczniów (Kłosek, 2005, s. 123). Krzysztof Nowak, podkreślając polityczny charakter zaistniałego w konsekwencji konfliktu, nazwał ówczesne działania w tym zakresie sporem „o dusze góralskie" (Nowak, 2000, s. 207). Inicjatywy strony słowackiej realizowane były poprzez szkołę i Kościół, a agitacja przyjmowała najróżniejsze formy - np. w Pojanie Mikuli dzięki zaangażowaniu nauczyciela Rudolfa Kovalika powstał słowacki chór kościelny i Stowarzyszenie Kulturalne im. T. G. Masaryka (Kłosek, 2005, ss. 123-125; Nowak, 2000, s. 208). Zorganizowane działania strony słowackiej wywołały odpowiedź strony polskiej - sprawa Bukowiny zaczęła pojawiać się na łamach prasy, a Związek Polaków w Rumunii zaczął domagać się interwencji rządu polskiego (Kłosek, 2005, s. 126). Jak pisze Kłosek, podjęto swoistą „akcję ratowniczą", w ramach której zorganizowano latem 1937, 1938 i 1939 roku wycieczki polskich letników do Pojany Mikuli; ich celem było przede wszystkim uatrakcyjnienie wizerunku Polski i Polaków w oczach miejscowej ludności. Wycieczki te przyniosły też wymierne korzyści materialne mieszkańcom wsi (Kłosek, 2005, s. 127). Do końca 1938 roku udało się też działaczom przywrócić naukę języka polskiego m.in. w Pojanie Mikuli, Nowym Sołońcu, Pleszy i Kaczyce (Kłosek, 2005, s. 129). Konflikt osiągnął swe apogeum w roku 1938, kiedy akcja agitacyjna strony słowackiej sprowokowała wizytę w Pojanie Mikuli inspekcji złożonej z prefektów Czerniowiec i Kympulungu, księdza Łukasiewicza i dr. Żukowskiego, zastępcy 
prezesa Polskiego Związku Szkolnego: Polacy z Pojany Mikuli niemal jednogłośnie stwierdzili wówczas, że chcą posyłać dzieci do szkoły polskiej, nie słowackiej (Kłosek, 2005, ss. 129-130). Konflikt trwał aż do roku 1944, a jak zauważa E. Kłosek, zastanawiająca była w tym kontekście labilność ideologiczna górali czadeckich pod koniec okresu międzywojennego. Badacz tłumaczy ją faktem, że opuszczając na przełomie XVIII i XIX wieku Czadeckie, ludność ta nie miała ukształtowanej tożsamości narodowej - jej ideologizacja nastąpiła dopiero na Bukowinie pod wpływem czynników zewnętrznych (Kłosek, 2005, s. 132). Etnonim Słowacy, jakim określają górali czadeckich mieszkańcy Bulaju, Rudy czy Kaczyki, jak wskazuje E. Kłosek, nie musi spełniać kryterium identyfikatora etnicznego, a wskazywać może wyłącznie na określoną "terytorialność" (Kłosek, 2005, ss. 133-134); zwłaszcza że trudno podać przyczyny, dla których górale czadeccy po przybyciu na Bukowinę zaczęli być nazywani Słowakami (Feleszko, 1995, ss. 155-157).

H. Krasowska zauważa, że w Nowym Sołońcu, Pleszy i Pojanie Mikuli gwara polska funkcjonuje w każdej z domen, a „Dzieci z rodzin polskich w Nowym Sołońcu, Pojanie Mikuli i Pleszy nie znają języka rumuńskiego do momentu rozpoczęcia nauki szkolnej" (Krasowska, 2006, s. 117). Podobne wnioski płyną z analizy najnowszego materiału gwarowego, przedstawionego w publikacji Świadectwo zanikającego dziedzictwa. Mowa polska na Bukowinie: Rumunia - Ukraina; np. w Nowym Sołońcu „Zarówno dorośli, jak i dzieci posługują się polską gwarą górali bukowińskich, również Ukraińcy mieszkający tutaj znają tę gwarę" (Krasowska i in., 2018, s. 70). Nowy Sołoniec (mieszka tam ponad 500 Polaków), Pojana Mikuli (około 450 Polaków) i Plesza (około 200 Polaków) (Krasowska i in., 2018, ss. 70-72) to miejscowości leżące w sąsiedztwie, obok siebie - jest to prawdziwie polska enklawa na Bukowinie rumuńskiej. Ludzie mieszkający w tych wsiach często się spotykają, mają również poczucie własnej odrębności od pozostałych grup Polaków w Rumunii - w tym także językowej: jako jedyni na Bukowinie rumuńskiej "gwarią", jak nazywają swoją mowę (por. Krasowska i in., 2018, ss. 87-88).

Różnice pomiędzy góralami bukowińskimi a społecznościami Bulaju, Rudy i Kaczyki nie wyczerpują się wyłącznie w odniesieniu do obszaru ich funkcjonowania w społeczeństwie rumuńskim. Górale (jako jedyna z czterech grup użytkowników polszczyzny) utrzymują bardzo ścisłe związki z Polską oraz instytucjonalny kontakt z tymi mieszkańcami wsi, którzy po II wojnie światowej w ramach reemigracji osiedlili się w Polsce: „W badanych wsiach istnieją zespoły folklorystyczne, które często występują w Polsce. Dzieci z polskich rodzin wyjeżdżają na wakacje i kolonie do historycznej ojczyzny" (Krasowska i in., 2018, s. 117). 
Funkcjonują tu: Zespół Górali Czadeckich „Sołonczanka” z Nowego Sołońca oraz Zespół Górali Czadeckich "Mała Pojana” z Pojany Mikuli. Zespoły te często spotykają się z osobami tworzącymi podobne formacje folklorystyczne nie tylko w Polsce, ale i na Ukrainie (jak np. Zespół Górali Czadeckich „Wianeczek” z Piotrowiec Dolnych czy Zespół Górali Czadeckich „Dolinianka” ze Starej Huty). Mieszkający w Polsce górale bukowińscy oraz ich potomkowie od dawna działają aktywnie na polu upowszechniania swoich tradycji i kultury. Magdalena Pokrzyńska wymienia aż 12 formacji, które reprezentują społeczność polskich górali czadeckich: Zespół Pieśni i Tańca „Pojana” z Piławy Dolnej, Zespół Górali Czadeckich „Watra” z Brzeźnicy, Zespół Górali Czadeckich „Dolina Nowego Sołońca” ze Złotnika, Zespół Górali Czadeckich „Dawidenka” z Koźlic, Góralski Teatr Pieśni „Dunawiec” ze Zbylutowa, Zespół Obrzędowy Górali Czadeckich "Jastrowiacy” z Jastrowia, Zespół Górali Czadeckich "Wichowianki” z Wichowa, Zespół Górali Czadeckich „Tajdany” ze Strzegomian, Dziecięcy Zespół Górali Czadeckich „Dziordanki” z Jastrowia, Dziecięcy Zespół Górali Czadeckich „Źródełko” z Wichowa, Zespół „Podgrodzianki” z Raciborowic Górnych, Zespół Górali Czadeckich „Jodełki” z Żagania (Pokrzyńska, 2010, ss. 121-125). Prócz tego w środowisku bukowińskim funkcjonują dwie organizacje integracyjno-pomocowe: Fundacja Bukowińska "Bratnia Pomoc” - założona w 1992 roku w Lubaniu Śląskim (w ramach której działa również chór "Echo Bukowiny”) oraz Stowarzyszenie „Wspólnota Bukowińska” istniejące od roku 1999 (Pokrzyńska, 2010, ss. 125-126). Od roku 1989 w Jastrowiu zaczęto organizować cykliczny festiwal "Spotkania Bukowińskie”, którego organizatorem jest Pilski Dom Kultury. Jak pisze Pokrzyńska:

„Przez pierwsze lata był to Festiwal Folkloru Górali Czadeckich (tzw. górale czadeccy z Polski, Rumunii i Ukrainy). Po dwóch latach organizatorzy zauważyli, że »bukowińska tradycja otwartości znajduje nadal wielu zwolenników« (Kowalski, 2002, s. 16), w związku z czym Piła i Jastrowie mogą się stać miejscem ukazywania wielonarodowościowej Bukowiny [...]. Od 1992 roku festiwal nosi nazwę Międzynarodowy Festiwal Folklorystyczny »Bukowińskie Spotkania«. Organizatorzy sukcesywnie powiększali grono uczestników festiwalu. Obecnie biorą w nim udział reprezentanci wszystkich - historycznych grup etnicznych Bukowiny. Od 2001 roku podpisywane jest co roku polsko-rumuńsko-ukraińsko-węgierskie porozumienie, dzięki któremu festiwal odbywa się w kilku edycjach i w różnych miejscach: w Polsce, na Węgrzech, w Rumunii i na Ukrainie. Jak podsumowuje główny organizator: 'To wyznacza »Bukowińskim Spotkaniom« wyjątkowe miejsce w gronie międzynarodowych festiwali folklorystycznych w Europie. Stały się największą imprezą w Europie - prezentują 
folklor jednego regionu - realizowaną w czterech krajach, gromadząc mieszkańców oraz uchodźców i ich potomków' (Kowalski, 2002, ss. 97-98). Od 2008 roku festiwal odbywa się również w Słowacji" (Pokrzyńska, 2010, s. 142).

Zespoły górali czadeckich z Rumunii biorą aktywny udział w „Bukowińskich Spotkaniach". To na terenie jednej z góralskich wsi (w Nowym Sołońcu) odbywają się również od wielu lat dożynki w ramach corocznego, cyklicznego wydarzenia pod nazwą Dni Polskie, organizowanego przez Związek Polaków w Rumunii z siedzibą w Suczawie.

Grupa górali bukowińskich jako jedyna posiada własne zespoły folklorystyczne i w sposób zorganizowany rozwija i kultywuje własne tradycje. Dla członków tej społeczności, w odróżnieniu od Polaków w Bulaju, Rudzie i Kaczyce, język jest istotnym elementem ich tożsamości - ciągle żywym i przydatnym, w dodatku nobilitującym ich w relacjach z przedstawicielami górali bukowińskich mieszkających w innych państwach Europy oraz w kontaktach z Polakami. Niebagatelne znaczenie ma także fakt, że duszpasterzami w tych miejscowościach są również Polacy: proboszczem parafii w Nowym Sołońcu jest ksiądz Stanisław Kucharek, w Pleszy pracuje ksiądz Andrzej Staszkowian (obaj pochodzą z Bukowiny rumuńskiej), natomiast w Pojanie Mikuli opiekę duszpasterską sprawuje ksiądz pochodzenia rumuńskiego Gabriel Bucur, który nauczył się miejscowej gwary. Ponadto w tych trzech wioskach nauczanie języka polskiego trwało nieprzerwanie od roku 1944 (Beleş, 2006, ss. 289-297). Niezwykle istotny jest także fakt, iż obecni liderzy mniejszości polskiej: prezes Związku Polaków w Rumunii Gerwazy Longher (piastujący tę funkcję od roku 2002) oraz posłanka mniejszości polskiej do parlamentu rumuńskiego Wiktoria Longher (prywatnie małżeństwo) mają w Nowym Sołońcu dom i rodzinę oraz zarówno oni, jaki i ich dzieci mówią gwarą górali czadeckich. Krasowska w swojej rozprawie odnotowała: „Najważniejszym elementem świadczącym o świadomości narodowej jest język, w tym i gwara, którą posługują się górale we wszystkich zbadanych przeze mnie miejscowościach" (Krasowska, 2006, s. 142). Gwara górali bukowińskich, w odróżnieniu od gwar Bulaju, Rudy i Kaczyki, nie zanika, lecz cieszy się wysokim prestiżem i jest obecna we wszystkim domenach w wymiarze lokalnym, co potwierdzają najnowsze badania (por. Krasowska i in., 2018, ss. 84-96).

Jak się wydaje, to właśnie sytuacja konfliktu, która miała miejsce w historii górali bukowińskich, doprowadziła do tego, że „piętno języka” stało się w wypadku tej grupy czynnikiem wywołującym zjawisko podobne do reakcji nazwanej przez E. Goffmana "wyzywającą arogancją" (Goffman, 2005, s. 50). Zaprzeczenie wartości języka, konieczność „opowiedzenia się" po stronie własnej gwary, wymóg jej nazwania oraz w pełni świadomego przyjęcia konsekwencji wyboru stanowiska wobec języka sprawiły, że w wypadku górali bukowińskich 
odzyskał on moc atrybutu. Jednocześnie konotacje, które mogły stanowić o negatywnym jego postrzeganiu jako piętna, uległy osłabieniu. Wartość języka - własnego kodu, który tę grupę wyróżniał i nadal wyróżnia - okazała się czynnikiem decydującym o jego żywotności.

\section{Zakończenie}

Jak wynika z powyższych rozważań, w wypadku gwar polskich na Bukowinie rumuńskiej sytuacja, w której gwara górali bukowińskich stała się przedmiotem dyskusji i sporów nie tylko językoznawczych, ale także politycznych, okazała się w konsekwencji jedną z przyczyn jej zachowania w tej grupie użytkowników polszczyzny. Polacy w Rumunii posługujący się tzw. gwarami małopolskimi, czyli mieszkańcy Bulaju (oraz Mihowen i Frumosy), Rudy i Kaczyki nie musieli zmagać się z tego typu wyzwaniami. Jednak to właśnie oni doświadczyli działania piętna języka, i to ich gwary zanikają, będąc obecnie jedynie świadectwem bogatej historii tych społeczności. Tylko wśród górali bukowińskich istnieje pokoleniowa transmisja gwary. Dla nich stała się ona uświadomionym elementem tożsamości etnicznej i stanowi rzeczywistą wartość. Wydaje się więc, że w tym wypadku konfrontacja na polu polityki językowej okazała się skuteczniejsza z punktu widzenia transmisji językowej niż podejmowane w nadziei na zachowanie jej ciągłości próby uniknięcia konfliktu, które najpewniej naraziłyby badaną mniejszość na jeszcze wyraźniejszą dominację polityczną, społeczną, czy świadomościową kulturowej większości.

\section{Bibliografia}

Beleş, L. (2006). Szkolnictwo polonijne trzech wsi na Bukowinie rumuńskiej. W Z. Kowalski, H. Krasowska, J. Makar, \& W. Strutyński (Red.), Bukowina: Tradycje i współczesność (ss. 289-299). Związek Polaków w Rumunii.

Biedrzycki, E. (1973). Historia Polaków na Bukowinie. Wydawnictwo Uniwersytetu Jagiellońskiego. Deboveanu, E. (1971). Polska gwara Górali bukowińskich w Rumunii (S. Gogolewski, Tłum.). Zakład Narodowy im. Ossolińskich; Wydawnictwo Polskiej Akademii Nauk.

Deboveanu, E., \& Gogolewski, S. (1966). Przegląd gwar polskich na terenie Rumunii. Język Polski, 1966(66), 112-131.

Feleszko, K. (1995). Tożsamość językowa, czyli: kto zasiedlił kilka wiosek Bukowiny? W K. Feleszko, J. Molas, \& W. Strutyński (Red.), Bukowina: Blaski i cienie „Europy w miniaturze” (ss. 153-165). Wydawnictwo Energeia.

Feleszko, K. (1999). O legendzie bukowińskiej - prozą (czyli kilka pojęć socjologicznych). W K. Feleszko (Red.), Bukowina po stronie dialogu (ss. 49-64). Pogranicze. 
Głuszkowski, M. (2011). Socjologiczne i psychologiczne uwarunkowania dwujęzyczności staroobrzędowców regionu suwalsko-augustowskiego. Wydawnictwo Naukowe Uniwersytetu Mikołaja Kopernika. Goffman, E. (2005). Piętno: Rozważania o zranionej tożsamości (A. Dzierżyńska \& J. Tokarska-Bakir, Tłum.). Gdańskie Towarzystwo Psychologiczne.

Gotkiewicz, M. (1938). Szukamy krewnych na Bukowinie. Zaranie Śląskie, 14(5), 273-284.

Holdeman, J. (2002). Language maintenance and shift among the Russian Old Believers of Erie, Pennsylvania [Niepublikowana praca doktorska]. Ohio State University.

Institutul Naţional de Statistică. (b.d.-a). Populaţia stabilă pe judeţe, municipii, oraşe şi localităti componenete la RPL_2011. http://www.recensamantromania.ro/rezultate-2/

Institutul Naţional de Statistică. (b.d.-b). Populaţia stabilă (rezidentă) - Structura etnică şi confesională. http://www.recensamantromania.ro/noutati/volumul-ii-populatia-stabila-rezidenta -stru-ctura-etnica-si-confesionala/

Kłosek, E. (2005). Świadomość etniczna i kultura społeczności polskiej we wsiach Bukowiny rumuńskiej. Katedra Etnologii i Antropologii Kulturowej Uniwersytetu Wrocławskiego.

Konstytucja Rumunii / Constituţia României. (b.d.). http://biblioteka.sejm.gov.pl/wp-content /uploads/2016/03/Rumunia_pol_010711.pdf

Kowalski, Z. (2002). „Bukowińskie Spotkania”. W C. Osękowski (Red.), Polacy z Bukowiny: Ich losy i kultura-źródłem tożsamości narodowej: Materiały z Międzynarodowego Sejmiku Krajoznawczego PTTK Żary 8-10 czerwca 2001 roku (ss. 95-101). PTTK Oddział Powiatu Żarskiego.

Krasowska, H. (2006). Górale polscy na Bukowinie Karpackiej: Studium socjolingwistyczne i leksykalne. Instytut Slawistyki Polskiej Akademii Nauk (Slawistyczny Ośrodek Wydawniczy).

Krasowska, H., Pokrzyńska, M., \& Suchomłynow, L. (2018). Świadectwo zanikajacego dziedzictwa: Mowa polska na Bukowinie: Rumunia - Ukraina. Instytut Slawistyki Polskiej Akademii Nauk. https://hdl.handle.net/20.500.12528/625

Libura, A. (2014). Atrycja języka odziedziczonego. W A. Dąbrowska \& U. Dobesz (Red.), 40 lat wroclawskiej glottodydaktyki polonistycznej: Teoria ipraktyka (ss. 303-312). Oficyna Wydawnicza ATUT.

Małecki, M. (1938). Język polski na południe od Karpat (Spisz, Orawa, Czadeckie, wyspy językowe). Gebethner i Wolff.

Małecki, M., \& Nandriş, G. (1938). Uwagi o polskich gwarach na Bukowinie. Sprawozdania z czynności i posiedzeń Polskiej Akademii Umiejętności, 43(3), 79-84.

Ministerul Educaţiei și Cercetării. (b.d.). Învățământ minorităţi naționale. https://www.edu.ro /invatamant-minoritati-nationale

Ministerul Educaţiei Naţionale și Cercetării Științifice. (b.d.). Direcția pentru Învățământ în Limbile Minorităților. (b.d.). http://oldsite.edu.ro/index.php/articles/c23

Nowak, K. (2000). „O dusze” górali bukowińskich: Polsko-czechosłowacki konflikt na Bukowinie po I wojnie światowej. W K. Feleszko (Red.), O Bukowinie: Razem czy oddzielnie (ss. 207-221). Pilski Dom Kultury; Instytut Filologii Słowiańskiej Uniwersytetu Warszawskiego.

Petraru, M. (2004). Polacy na Bukowinie w latach 1775-1918: Z dziejów osadnictwa polskiego (A. Kaźmierczak, Tłum.). Wydawnictwo Uniwersytetu Jagiellońskiego.

Pokrzyńska, M. (2010). Bukowińczycy w Polsce: Socjologiczne studium rozwoju wspólnoty regionalnej. Uniwersytet Zielonogórski. 
Rossmanith, A. (2017). Język polski, struktura etniczna i religijna w skupiskach polskich na Bukowinie w latach 2011-2013 w świetle badań terenowych. W E. Wieruszewska-Calistru \& K. Stempel-Gancarczyk (Red.), Historia i dzień dzisiejszy relacji polsko-rumuńskich / Istoria și prezentul relațiilor polono-române (ss. 404-415). Związek Polaków w Rumunii.

Stempel-Gancarczyk, K. (2015). „Kim jesteśmy?”: Uwagi o języku polskich mieszkańców Bulaju oraz ich "mazurskiej” autoidentyfikacji. W S. lachimovschi, K. Stempel-Gancarczyk, \& E. Wieruszewska-Calistru (Red.), Polska i Rumunia: Wspólnie - obok - blisko / Polonia și România: Împreună - alături - aproape (ss. 395-401). Związek Polaków w Rumunii.

Stempel-Gancarczyk, K. (2016a). Bucovina secolului al XX-lea - o Arcadie în amintirile membrilor comunităţii polonezilor din România (pe baza interviurilor și a materialelor scrise din localităţile Bulai și Vicșani). Analele Bucovinei, 1(46), 155-163.

Stempel-Gancarczyk, K. (2016b). Społeczności polskie w Bulaju i Rudzie - mowa pogranicza. W K. Stempel-Gancarczyk \& E. Wieruszewska-Calistru (Red.), Historyczne i kulturowe aspekty relacji polsko-rumuńskich / Aspectele istorice și culturale ale relațiilor polono-române (ss. 299-306). Związek Polaków w Rumunii.

Stempel-Gancarczyk, K. (2017a). Catolicismul polonez în Bucovina românească - tradiție și eclectism (studiu de caz: Bulai-Moara). Analele Bucovinei, 2(49), 421-428.

Stempel-Gancarczyk, K. (2017b). Pamięć Bukowiny - pomiędzy arkadyjską „pozłotą wspomnień" a rzeczywistością historyczną - na podstawie wywiadów i opracowań dotyczących miejscowości Bulai (Bulaj) i Vicşani (Wikszany, Ruda). W E. Wieruszewska-Calistru \& K. Stempel-Gancarczyk (Red.), Historia i dzień dzisiejszy relacji polsko-rumuńskich / Istoria și prezentul relațiilor polono-române (ss. 416-429). Związek Polaków w Rumunii.

Stempel-Gancarczyk, K. (2018). Biografie językowe a zanikanie gwar polskich na Bukowinie: Wybrane aspekty. W K. Stempel-Gancarczyk \& E. Wieruszewska-Calistru (Red.), Zwiqzki polsko-rumuńskie w historii i kulturze / Legăturii istorice şi culturale polono-române (ss. 478-489). Związek Polaków w Rumunii.

Stempel-Gancarczyk, K. (2019). Procesy zanikaniajęzyka na podstawie badań gwar polskich na Bukowinie rumuńskiej [Niepublikowana praca doktorska]. Instytut Slawistyki Polskiej Akademii Nauk. Wieruszewska, E. (2006). Związek Polaków w Rumunii (1990-2006). W Z. Kowalski, H. Krasowska, J. Makar, \& W. Strutyński (Red.), Bukowina: Tradycje i współczesność (ss. 267-278). Związek Polaków w Rumunii.

Zielińska, A. (2013). Mowa pogranicza: Studium o językach i tożsamościach w regionie lubuskim. Instytut Slawistyki Polskiej Akademii Nauk. https://hdl.handle.net/20.500.12528/37

\section{Stigma versus the Value of a Language: The Situation of Polish Dialects in Romanian Bukovina}

This article presents the current situation of users of local dialects of the Lesser Poland regional dialect of Polish (gwary małopolskie) in Romanian Bukovina. Owing to demographic processes as well as social and cultural conditions, their number continues to fall. The latest research indicates that in the case of several villages with the Polish population it is difficult 
to talk about local dialects anymore: they have been substituted with what can be more adequately referred to as "a group of idiolects". Such communities in Romanian Bukovina are composed of people whose ancestors originally came from the Lesser Poland region in Poland. By contrast, Bukovinian highlanders are the only group of Poles in Romania in which local dialect is still passed between generations. The article attempts to answer the question why only in this group the dialectal speech of their ancestors has remained a value, as apparent in its intergenerational transmission.

\section{Keywords:}

Romanian Bukovina; Polish dialects; Bukovinian highlanders; language as a value; language as a testimony; stigma

\section{Piętno a wartość języka. Sytuacja gwar małopolskich na Bukowinie rumuńskiej}

Artykuł zawiera opis współczesnej sytuacji socjolingwistycznej użytkowników gwar małopolskich na Bukowinie rumuńskiej. Procesy demograficzne oraz uwarunkowania społeczno-kulturowe sprawiły, że liczba ich użytkowników jest coraz mniejsza. Jak udowadniają najnowsze badania, w wypadku niektórych miejscowości zamieszkałych przez Polaków trudno już mówić o gwarach - ze względu na liczbę użytkowników bardziej adekwatnym określeniem może wydawać się określenie „zespół idiolektów”. Do tego typu społeczności należą użytkownicy gwar małopolskich na Bukowinie rumuńskiej. Niejako w opozycji do nich sytuują się górale bukowińscy, jedyna grupa Polaków w Rumunii, w której obecna jest pokoleniowa transmisja gwary. Zasadniczą treścią artykułu jest próba odpowiedzi na pytanie, jakie czynniki sprawiły, że tylko w tej grupie użytkowników język przodków pozostał żywotną wartością, co przejawia się w obecności transmisji pokoleniowej gwary.

\section{Słowa kluczowe:}

Bukowina rumuńska; gwary polskie; górale bukowińscy; język jako wartość; język jako świadectwo; piętno

\section{Citation:}

Stempel-Gancarczyk, K. (2020). Piętno a wartość języka: Sytuacja gwar małopolskich na Bukowinie rumuńskiej. Adeptus, 2020(15), Article 2155. https://doi.org/10.11649/a.2155

\section{Publication History:}

Received: 2019-10-10; Accepted: 2020-04-30; Published: 2020-06-30 